\title{
Systemic sclerosis (scleroderma): remaining challenges
}

\author{
Mary Karin Connolly \\ Department of Dermatology, University of California, San Francisco, San Francisco, CA 94115, USA \\ Correspondence to: Mary Karin Connolly, MD. Department of Dermatology, University of California, San Francisco, Box 1790, San Francisco, CA \\ 94115, USA. Email: connolly@ucsf.edu.
}

\begin{abstract}
Despite progress in treating internal organ involvement in systemic sclerosis (scleroderma) (SSc), such as pulmonary disease, effective treatments for the hallmark of the disease, cutaneous fibrosis, remain elusive. None of the disease-modifying antirheumatic drugs (DMARDS) have shown proven efficacy for SSc skin fibrosis, and there remain no FDA-approved medications, all of which are off-label, for cutaneous fibrosis in SSc. This review article will briefly summarize conventional therapies, biologics and hematopoietic stem cell transplants and select ongoing clinical trials in SSc. The gold standard for measuring skin fibrosis in SSc is the modified Rodnan skin score (MRSSS). This is a validated test that measures skin thickness $(0$ to 3 ) at 17 locations for a total score of 51 . Improvements in skin score over time are used in clinical trials to quantitate skin fibrosis. Although recording the Rodnan skin score is technically straightforward, requiring no special equipment, and noninvasive, the fluctuating natural history of the disease includes improvement over time without interventions, rendering meaningful trials difficult to assess. Understanding of the basic molecular mechanisms driving pathologic fibrosis in SSc remains lacking, and underpins the often empiric nature and likely the lack of efficacy of many therapeutics that have been tried. Although repeated skin biopsies might be a more precise way to follow disease progression and regression, this is necessarily invasive and requires special tools. Here, this review will look at conventional therapies, biologics, autologous hematopoietic stem cell transplantation, and catalog some of the ongoing clinical trials in SSc with a focus on cutaneous fibrosis.
\end{abstract}

Keywords: Systemic sclerosis; therapy; biologicals; clinical trials

Submitted Jul 22, 2020. Accepted for publication Dec 31, 2020.

doi: $10.21037 /$ atm-20-5449

View this article at: http://dx.doi.org/10.21037/atm-20-5449

\section{Introduction/conventional therapies in SSc (Table 1)}

Therapies in SSc are divided into three broad categories: (I) anti-immunologic and anti-inflammatory medications that target dysregulated immune and inflammatory pathways; (II) anti-fibrotic medications that target extracellular matrix and collagen production pathways; and (III) vascular medications to improve blood flow in Raynaud's phenomenon and treat pulmonary artery hypertension. We will organize this review according to these general categories (1-3).

Despite the widespread use of corticosteroids and immunosuppressive drugs in clinical practice, conclusive trial data that support the use of these medications remain lacking (4). It is challenging to do clinical trials in SSc because of its low prevalence, its diverse clinical manifestations, and its variable and fluctuating course. Aside from low-dose prednisone for arthralgias, moderate to high doses of prednisone are contraindicated in SSc because of their association with scleroderma renal crisis (1). Although prednisone has been very effective in treating systemic lupus erythematosus or polymyositis/dermatomyositis, particularly in combinations with other DMARDs, efficacy in SSc has not been shown and significant side effects continue to limit its use.

Conventional therapies for SSc include the immunosuppressive agents methotrexate, azathioprine, mycophenolate mofetil (MMF) and cyclophosphamide (CYC) (Table 1) (1,5). These drugs work by broadly suppressing the immune system thought to play a critical 
Table 1 Current treatment options for internal organs in SSc

\begin{tabular}{ll}
\hline Internal organs & Medications \\
\hline Gastrointestinal: upper (GERD) & Proton pump inhibitors \\
Lower: constipation & Promotility agents \\
Pulmonaryea & Antibiotics \\
Interstitial lung disease (ILD) & Immunosuppression: \\
& Cyclophosphamide \\
& Mycophenolate mofetil \\
Pulmonary artery hypertension & Endothelial receptor antagonist \\
(PAH) & Phosphodiesterase inhibitors \\
& Prostacyclin analogs \\
& Prostacyclin receptor agonist \\
Kidney: Scleroderma renal crisis & ACE inhibitors \\
Musculoskeletal system joints & Methotrexate
\end{tabular}

SSc, systemic sclerosis; GERD, gastrointestinal reflux disease; ACE inhibitors, angiotensin-converting enzyme inhibitors; ILD, interstitial lung disease; $\mathrm{PAH}$, pulmonary artery hypertension.

role in the pathogenesis of SSc. Methotrexate is used for musculoskeletal involvement, which is common, and includes both arthritis/arthralgias and myositis/myalgias (1), and efficacy has been demonstrated among adults with SSc (6). Methotrexate has also shown success in treating children with juvenile localized scleroderma $(7,8)$. For these reasons, MTX is considered somewhat effective and safe. One drawback of MTX is minimal activity in interstitial lung disease (ILD), which occurs frequently in SSc and remains the most common cause of death. Further, MTX can itself cause pneumonitis that is hard to differentiate from ILD. For this reason, alternative agents, including azathioprine, MMF and CYC, are preferred because they been shown to have some benefit in SSc-ILD (9-11). CYC can be given as an oral daily dose or a monthly IV infusion (1). After an induction phase, patients are switched to either AZA or MMF for a maintenance phase due to their lower toxicity as compared to continuation of CYC. Between the two, MMF is preferred over AZA because of its demonstrable efficacy and its increased tolerance with fewer side effects. In general, these immunosuppressive medications are associated with improved lung function and skin scores. Both have potential serious side effects and require laboratory monitoring.

\section{Biological therapies and hematopoietic stem cell transplantation (HSCT) in SSc}

The original biologic was intravenous immunoglobulin (IVIg) created from pools of thousands of plasma donors was one of the first biologic products, First used in the 1980s, IVIg was initially used to restore antibody levels in patients with primary immunoglobulin deficiency, where it proved life-saving. The precise mechanism whereby IVIG works is not completely understood, one mechanism is by saturating the neonatal Fc receptor, FcRn, which normally serves to recycle adsorbed antibodies and return them to serum, IVIg reduces endogenous antibody levels, including autoantibodies, by promoting accelerated clearance, and has shown efficacy in a number of antibody-mediated autoimmune diseases. Among patients with early acute severe diffuse SSc, there are only small trials and case reports indicating some efficacy $(12,13)$, and further study is needed.

Biologicals refer to a class of medications made by recombinant DNA technology and include cytokines and monoclonal antibodies targeting a variety of cells, cytokines and receptors (5). A theoretical advantage of biologicals is the specificity of the target, in contrast to the broad effects on the immune system that are associated with conventional immunosuppressive medications like corticosteroids. Tumor necrosis factor alpha (TNF-alpha) antibodies targeting the cytokine or its receptor were among the first biologics with success in human autoinflammatory diseases, where they have been used with success in treating rheumatoid arthritis, psoriasis and psoriatic arthritis, spondyloarthritis and inflammatory bowel disease (1). Unfortunately, these drugs have shown little efficacy in SSc $(14,15)$. Recombinant interferon-alpha, despite some efficacy in multiple sclerosis, was not effective for SSc (16), nor were efforts to block the type 1 interferon (IFN) receptor using MEDI-456 (17).

Transforming growth factor beta (TGF beta) is an ubiquitous growth factor associated with fibrosis and associated with the pathogenesis of SSc, and efforts to block its effects in a variety of fibrosing syndromes of humans are ongoing. A small phase I/II trial with a human recombinant neutralizing TGF-beta 1 antibody (CAT-192) was unable to show benefit as compared to placebo (18). A current trial is using Fresolimumab, a human IgG4 kappa recombinant 
monoclonal antibody capable of neutralizing all forms of TGF-beta, perhaps increasing the likelihood to attacking the multiple different isoforms of the growth factor (19).

Rituximab (RTX) is a chimeric monoclonal antibody against CD20, which is expressed on pre-B cells and B-cells, which can target and remove potentially pathogenic autoantibody-producing B cells. There are several open label trials with small numbers of patients that suggest some benefit in skin and lung disease (5), but larger randomized control trials are needed; these are underway (20-30). Although there is an increased risk of infections with RTX, but most were mild and could be managed in the outpatient setting with replacement antibody therapy as necessary.

Interleukin 6 (IL-6) is a cytokine that has also been associated with fibrosis and inflammation. Tocilizumab is a humanized antibody against the IL-6 receptor that was initially used in rheumatoid arthritis with some success. It was tried on 2 patients with diffuse SSc and based on success then expanded to a phase $2 / 3$ trial (31-35), which showed a trend toward skin and lung improvement in 87 patients (5). A larger, multicenter trial $(\mathrm{N}=210)$ in SSc has been completed and did not meet their primary endpoints (36).

IL-1 is another cytokine associated with inflammation and fibrosis. Blockers of IL-1 have been used in CAPS (cryopyrin-associated periodic syndromes), DIRA (deficiency of IL-1 receptor antagonist and JIA (juvenile idiopathic arthritis) (5). A well-design trial using biomarkers from skin biopsies as well as the standard MRSS, however, was unable to show efficacy of the drug on biomarkers of disease or the MRSS (37).

Abatacept (CTLA-4Ig) is a fusion protein that blocks $T$ cell activity and has shown efficacy among patients with rheumatoid arthritis. It has also shown some benefit in joint and muscle involvement with SSc $(38,39)$.

Because of their therapeutic successes in a variety of inflammatory diseases, including rheumatoid arthritis and psoriasis, various Janus kinase inhibitors will undoubtedly be used in patients with SSc, particularly given some success in preclinical models.

Hematopoietic stem cell transplantation (HSCT) was originally used to treat blood cancers of the blood or bone marrow such as leukemia and multiple myeloma in the 1950s. Radiation or chemotherapy was used to wipe out the patient's own bone marrow cells as a conditioning regimen is myeloablative. There are newer gentler regimens that are non-ablative that are better tolerated. It was recognized to be helpful in some autoimmune disorders such multiple sclerosis and SSc. These procedures do come with serious side effects and an increase mortality.

HSCT is the most extreme form of immunosuppression with both myeloablative and nonmyeloablative conditioning regimens and was first used in SSc in the 2000s. There have been quite a number of studies looking this intervention. Although there can be rapid improvement in skin and lung disease, it comes with a significant morbidity and mortality and an increase incidence of relapse. Therefore, it is only recommended for a select group of very severe early patients at select centers (40-64). The three largest studies 46, 49 and 60 include just over 300 patients and demonstrate that HSCT is superior to CYC with regard to event-free survival and survival. Because of the early expected morbidity and mortality with HSCT within the first year, it takes 2-years to start to see the benefit of HSCT, but that advantage remains for the follow up periods of 4 to 5 years follow up.

\section{Anti-fibrotics in SSc}

SSc is a disease characterized by an abundance of connective tissue production and increased extracellular matrix, particularly collagen in the skin and internal organs (65). Drugs that inhibit collagen production are considered antifibrotics and have a long history of use in SSc. Older drugs like D-Penicillamine, a chelating agent that blocks collagen production by inhibiting cross-linking, were used for many years but have fallen out of favor due to sideeffects and uncertain efficacy (1). Tyrosine kinase inhibitors (imatinib, dasatinib, nilotinib) are small molecules that block ABL-kinases and platelet derived growth factors that have been implicated in fibrotic pathways. The early trials in SSc were encouraging but no significant benefits have been reliably shown despite the occurrence of significant toxicities such as fluid retention and elevated creatinine kinases (66-69).

Pirfenidone has shown some success in the treatment of idiopathic pulmonary fibrosis in trials which also included some patients with SSc-ILD (70). Sirolimus (rapamycin) is an immunosuppressive drug used to prevent kidney transplant rejection that also has some efficacy in SSc (71).

There are a number of animal models of SSc that have been used to screen various drugs before human use (72). Halofuginone, a plant-derived alkaloid with antifibrotic properties has been used with some success in animal models.

\section{Vascular medications that are used in SSc}

Raynaud's phenomenon (RP) is extremely common in SSc 
Page 4 of 8

Table 2 Select ongoing clinical trials in SSc (ClinicalTrials.gov)

\begin{tabular}{|c|c|}
\hline Medication & Trials (references) \\
\hline Rituximab (RTX) & 12 listed trials: \\
\hline \multirow[t]{11}{*}{ Anti-CD20 B cells } & +belimumab, US \\
\hline & +methylprednisolone, Belgium \\
\hline & -For PAH, multicenter, US \\
\hline & -Efficacy \& safety, Japan \\
\hline & -For Localized scleroderma, EF, Belgium \\
\hline & -For Graft versus host disease, multicenter, \\
\hline & US \\
\hline & -RTX versus CYC, UK \\
\hline & -Cardiac safety, US \\
\hline & -RTX + HSCT for ILD, PAH, US \\
\hline & -ILD, PAH, Canada \\
\hline Tocilizumab & 3 listed trials: \\
\hline \multirow[t]{3}{*}{ Anti-IL6 receptor } & RCT, US (completed) \\
\hline & RCT, multicenter, US (completed) \\
\hline & RCT, Canada \\
\hline TGF-beta & 1 study, phase $1, N=18$ \\
\hline Fresolimumab & Multicenter, US for dSSc \\
\hline Tyrosine kinase & References: (65-68) \\
\hline $\begin{array}{l}\text { Inhibitors: Imatinib } \\
\text { (Gleevac) }\end{array}$ & RCT terminated, Canada 2008 \\
\hline Nilotinib & $\begin{array}{l}\text { RCT for SSc-ILD, phase } 3, \mathrm{~N}=580,150 \mathrm{mg} \\
\text { bid for } 1 \text { year, completed } 2018\end{array}$ \\
\hline Dasatinib & $\begin{array}{l}1 \text { phase } \mathrm{I} / \mathrm{II}, \mathrm{N}=47,2011 \text {, multicenter, US } \\
\text { discontinued because of side effects }\end{array}$ \\
\hline $\begin{array}{l}\text { Alemtuzumab/ } \\
\text { lemtruda }\end{array}$ & B-CLL (B-chronic lymphocytic leukemia) \\
\hline \multirow{3}{*}{$\begin{array}{l}\text { Campath-1H (anti- } \\
\text { CD52) }\end{array}$} & Multiple sclerosis, relapsing \\
\hline & Graft-versus-host disease \\
\hline & Children; Pilot I/II Withdrawn; 2018 \\
\hline Rilonacept & 1 Trial SSc, US \\
\hline \multicolumn{2}{|l|}{ IL-1 receptor } \\
\hline Abatacept & 1 Trial completed, US single center $(37,38)$ \\
\hline \multicolumn{2}{|l|}{ CTLA-4 } \\
\hline \multirow{4}{*}{$\begin{array}{l}\text { Hematopoietic stem } \\
\text { cell transplantation } \\
\text { (HSCT) (39-63) }\end{array}$} & $\begin{array}{l}23 \text { studies listed, looking at different conditioning } \\
\text { regimens, cardiac safety, ILD, +RTX }\end{array}$ \\
\hline & Children, other autoimmune diseases SLE, DM \\
\hline & Multicenter, US, Germany, China, France \\
\hline & ASSIST I conditioning regimen \\
\hline
\end{tabular}

SSc, systemic sclerosis; RTX, Rituximab; PAH, pulmonary artery hypertension; EF, eosinophilic fasciitis; US, Unites States; UK, United Kingdom; HSCT, hematopoietic stem cell transplant; ILD, interstitial lung disease; RCT, randomized controlled trial; dSSc, diffuse systemic sclerosis; SLE, systemic lupus erythematosus; DM, dermatomyositis; ASSIST, Autologous Stem Cell Systemic Sclerosis Immune Suppression Trial.
Connolly. Systemic sclerosis (scleroderma): remaining challenges

patients and reflects recurrent vasospasm of the small and medium peripheral blood vessels, particularly of the hands (73). Medical management with vasodilators, calcium channel blockers, and phosphodiesterase-5 inhibitors (PDE5), has been effective for RP and helps to reduce end-organ damage in other tissues. Botulimum toxin has been used successfully to treat RP (74).

In addition to the common small and medium-size vessel involvement of RP, there is also less common larger vessel involvement which can manifest as scleroderma renal crisis (SRC) and pulmonary arterial hypertension (PAH). ACE inhibitors have been shown to be very effective in treating SRC. There is also new therapies for PAH including PDE5 inhibitors, endothelin antagonist, prostacyclin and combination therapy (1).

\section{Select clinical trials in SSc (Table 2)}

There are 431 studies related to SSc (136 clinical trials) and 64 studies related to Raynaud's phenomenon on ClinicalTrials.gov.

The Scleroderma Clinical Trials Consortium (SCTC) is an active international organization that follows, organizes and participates in SSc trials. Their meetings and website can provide a wealth of information and help to physicians and patients interested in SSc.

\section{Conclusions}

Although there is some progress in treating this complex disease, there remain significant barriers and challenges. There are dedicated investigators who are designing and participating in quality clinical trials like the Scleroderma Clinical Trials Consortium. There are successful efforts to form collaborating coalitions that can work together. Nonetheless, despite many trials, aside from using immunosuppression for SSc-lung disease there are no effective skin fibrosis treatments available (1). Although a number of the biologicals have been tried, none have been shown to work in SSc (5). Despite these challenges, there are many dedicated investigators who continue to work hard with patients, academicians and industry to continue the rigorous clinical trials required to demonstrate the successes so sought after by all.

\section{Acknowledgments}

Funding: Dr. Connolly's funding comes from her full- 
time faculty position at the University of California, San Francisco. She does not receive any funding from industry or organizations.

\section{Footnote}

Provenance and Peer Review: This article was commissioned by the editorial office, Annals of Translational Medicine for the series "Rheumatologic Skin Disease". The article has undergone external peer review.

Conflicts of Interest: The author has completed the ICMJE uniform disclosure form (available at http://dx.doi. org/10.21037/atm-20-5449). The series "Rheumatologic Skin Disease" was commissioned by the editorial office without any funding or sponsorship. MKC served as the unpaid Guest Editor of the series. The author has no other conflicts of interest to declare.

Ethical Statement: The author is accountable for all aspects of the work ensuring that questions related to accuracy and intergrity of any part of the work are appropriately investigated and resolved.

Open Access Statement: This is an Open Access article distributed in accordance with the Creative Commons Attribution-NonCommercial-NoDerivs 4.0 International License (CC BY-NC-ND 4.0), which permits the noncommercial replication and distribution of the article with the strict proviso that no changes or edits are made and the original work is properly cited (including links to both the formal publication through the relevant DOI and the license). See: https://creativecommons.org/licenses/by-nc-nd/4.0/.

\section{References}

1. Wigley FM, Boin F. Clinical features and treatment of scleroderma. In: Kelley and Firestein's Textbook of Rheumatology 2017;10th ed:1424-1460.

2. Clements PJ, Lachenbruch PA, Ng SC, et al. Skin score: a semiquantitative measure of cutaneous involvement that improves prediction of prognosis in systemic sclerosis. Arthritis Rheum 1990;33:1256-63.

3. Whitfield ML, Finlay DR, Murray JI, et al. Systemic and cell type-specific gene expression patterns in scleroderma skin. Proc Natl Acad Sci U S A 2003;100:12319-24.

4. Hunzelmann N, Moinzadeh P, Genth E, et al. High frequency of corticosteroid and immunosuppressive therapy in patients with systemic sclerosis despite limited evidence of efficacy. Arthritis Res Ther 2009;11:R30.

5. Van Laar JM, Simms RW. Immunomodulatory, Immunoablative and Biologic therapies. In: Varga J, Denton C, Wigley F, et al., (eds) Scleroderma. Springer, Cha 2017;2nd ed:567-582.

6. Pope JE, Bellamy N, Seibold JR, et al. A randomized, controlled trial of methotrexate versus placebo in early diffuse scleroderma. Arthritis Rheum 2001;44:1351-8.

7. Zulian F, Martini G, Vallongo C, et al. Methotrexate treatment in juvenile localized scleroderma: a randomized, double-blind, Placebo-controlled trial. Arthritis Rheum 2011;63:1998-2006.

8. Zulian F, Vallongo C, Patrizi A, et al. A long-term followup study of methotrexate in juvenile localized scleroderma (morphea). J Am Acad Dermatol 2012;67:1151-6.

9. Paone C, Chiarolanza I, Cuomo G, et al. 12-month azathioprine as maintenance therapy in early diffuse systemic sclerosis patients treated for 1-year with low-dose cyclophosphamide pulse therapy. Clin Exp Rheumatol 2007;25:613-6.

10. Tashkin DP, Elashoff R, Clements PJ, et al. Cyclophosphamide versus placebo in scleroderma lung disease. N Engl J Med 2006;354:2655-66.

11. Tashkin DP, Roth MD, Clements PJ, et al. Mycophenolate mofetil versus oral cyclophosphamide in sclerodermarelated interstitial lung disease (SLSII): a randomized controlled, double-blind, parallel group trial. Lancet Respir Med 2016;4:708-19.

12. Takehara K, Ihn H, Sato S. A randomized, double-blind, placebo-controlled trial: intravenous immunoglobulin treatment with patients with diffuse cutaneous systemic sclerosis. Clin Exp Rheumatol 2013;31:151-6.

13. Poelman CL, Hummers LK, Wigley FM, et al. Intravenous immunoglobulin may be effective therapy for refractory, active diffuse cutaneous systemic sclerosis. J Rheumatol 2015;42:236-42.

14. Lam GK, Hummers LK, Woods A, et al. Efficacy and safety of etanercept in the treatment of sclerodermaassociated joint disease. J Rheumatol 2007;34:1636-7.

15. Denton CP, Engelhart M, Tvede N, et al. An open-label pilot study of infliximab therapy in diffuse cutaneous systemic sclerosis. Ann Rheum Dis 2009;68:1433-9.

16. Black CM, Silman AJ, Herrick AL, et al. Interfon-a does not improve outcome at one year in patients with diffuse cutaneous scleroderma: results of a randomized, double-blind, placebo-controlled trial. Arthritis Rheum 1999;42:299-305. 
17. Goldberg A, et al. Dose-escalation of human antiinterferon-alpha receptor monoclonal antibody MEDI-546 in subjects with systemic sclerosis: a phase I, multicenter, open-label study. Arthritis Res Ther 2014;16:R57.

18. Denton CP, Merkel PA, Furst DE, et al. Recombinant human anti-TGF-beta 1 antibody in SSc: a randomized, placebo-controlled phase I/II trial of CAT-192. Arthritis Rheum 2007;56:323-33.

19. Morris JC, Tan AR, Olencki TE, et al. Phase I study of GC1008 (fresolimumab): a human anti-transforming growth factor-beta (TGFbeta) monoclonal antibody in patients with advanced melanoma or renal cell carcinoma. PLoS One 2014;9:e90353.

20. Lafyatis R, Kissen E, York M, et al. B cell depletion with rituximab in patients with diffuse cutaneous systemic sclerosis. Arthritis Rheum 2009;60:578-83.

21. Jordan S, Distler JH, Mauer B, et al. Effects and safety of rituximab in systemic sclerosis: an analysis from the European Scleroderma Trial and Research (EUSTAR) group. Ann Rheum Dis 2015;74:1188-94.

22. Zulian F, Dal Pozzolo R, Meneghel A, et al. Rituximab for rapidly progressive juvenile systemic sclerosis. Rheumatology (Oxford) 2020;59:3793-7.

23. Caldas MMVF, Neto FAB, Azevedo KPM, et al. Rituximab for systemic sclerosis: a protocol for systemic review. Medicine (Baltimore) 2019;98:e17110.

24. Ebata S, Yoshizaki A, Fukasawa T, et al. Rituximab therapy is more effective than cyclophosphamide therapy for Japanese patients with anti-topoisomerase I-positive systemic sclerosis-associated interstitial lung disease. J Dermatol 2019;46:1006-13.

25. Elhai M, Boubaya M, Distler O, et al. Outcomes of patients with systemic sclerosis treated with rituximab in contemporary practice: a prospective cohort study. Ann Rheum Dis 2019;78:979-87.

26. Fraticelli P, Fischetti C, Salaffi F, et al. Combination therapy with rituximab and mycophenolate mofetil in systemic sclerosis. A single-centre case series study. Clin Exp Rheumatol 2018;36:142-5.

27. Sircar G, Goswami RP, Sircar D, et al. Intravenous cyclophosphamide vs rituximab for the treatment of early diffuse scleroderma lung disease: open label, randomized, controlled trial. Rheumatology (Oxford) 2018;57:2106-13.

28. Thiebaut M, Launay D, Riviere S, et al. Efficacy and safety of rituximab in systemic sclerosis: French retrospective study and literature review. Autoimmun Rev 2018;17:582-7.

29. Melsens K, Vandecasteele E, Deschepper E, et al. Two years follow-up of an open-label pilot of treatment with rituximab in patients with early diffuse cutaneous systemic sclerosis. Acta Clin Belg 2018;73:119-25.

30. Sharif K, Watad A, Bragazzi NL, et al. Anterior STelevation myocardial infarction induced by rituximab infusion: a case report and review of the literature. J Clin Pharm Ther 2017;42:356-62.

31. Khanna D, Denton CP, van Laar JM, et al. Safety and efficacy of subcutaneous tocilizumab in adults with systemic sclerosis: week 24 data from a phase 2/3 trial. Arthritis Rheum 2014;66:S833.

32. Zacay G, Levy Y. Outcomes of patients with systemic sclerosis treated with tocilizumab: case series and review of the literature. Best Pract Res Clin Rheumatol 2018;32:563-71.

33. Narváez J, LLuch J, Alegre Sancho JJ, et al. Effectiveness and safety of tocilizumab for the treatment of refractory systemic sclerosis associated interstitial lung disease: a case series. Ann Rheum Dis 2019;78:e123.

34. Denton CP, Ong VH, Xu S, et al. Therapeutic interleukin-6 reverses transforming growth factor-beta pathway activation in dermal fibroblasts: insights from the fascinate clinical trial in systemic sclerosis. Ann Rheum Dis 2018;77:1362-71.

35. Shima Y, Kawaguchi Y, Kumwana M. Add-on tocilizumab versus conventional treatment for systemic sclerosis, and cytokine analysis to identify an endotype to tocilizumab therapy. Mod Rheumatol 2019;29:134-9.

36. Khanna D, van Laar JM, Furst DE, et al. Tocilizumab in systemic sclerosis: a randomised, double-blind, placebo-controlled phase 3 trial. Lancet Respir Med 2020;8:963-74.

37. Mantero JC, Kishore N, Ziemek J, et al. Randomized, double-blind, placebo-controlled trial of IL-1 trap, Rilonacept, in systemic sclerosis. A phase I/II biomarker trial. Clin Exp Rheumatol 2018;36 Suppl 113:146-9.

38. Khanna D, Spino C, Johnson S, et al. Abatacept in early diffuse cutaneous systemic sclerosis: Results of a phase II investigator-initiated multicenter, double-blind, randomized, placebo-controlled trial. Arthritis Rheumatol 2020;72:125-36.

39. Castellví I, Elhai M, Bruni C, et al. Safety and effectiveness of abatacept in systemic sclerosis: the EUSTAR experience. Semin Arthritis Rheum 2020;50:1489-93.

40. Binks M, Passweg JR, Furst D, et al. Phase I/II trial of autologous stem cell transplantation in systemic sclerosis: procedure-related mortality and impact on skin disease. Ann Rheum Dis 2001;60:577-84. 
41. Farge D, Marolleau JP, Zohar S, et al. Autologous bone marrow transplantation in the treatment of refractory systemic sclerosis: early results of a French multicentre phase I-II study. Br J Haematol 2002;119:726-39.

42. Farge D, Passweg J, van Laar JM, et al. Autologous stem cell transplantation in the treatment of systemic sclerosis: report from the EBMT/EULAR registry. Ann Rheum Dis 2004;63:974-81.

43. Nash RA, McSweeney PA, Crofford LJ, et al. High-dose immunosuppressive therapy and autologous hematopoietic cell transplantation for severe systemic sclerosis: longterm follow-up of the US multicenter pilot study. Blood 2007;110:1388-96.

44. Vonk MC, Marjanovic Z, van den Hoogen FH, et al. Long-term follow-up results after autologous haematopoietic stem cell transplantation for severe systemic sclerosis. Ann Rheum Dis 2008;67:98-104.

45. Henes JC, Schmalzing M, Vogel W, et al. Optimization of autologous stem cell transplantation for systemic sclerosis - a single-center longterm experience in 26 patients with severe organ manifestations. J Rheumatol 2012;39:269-75.

46. Burt RK, Shah SJ, Dill K, et al. Autologous nonmyeloablative haemopoietic stem-cell transplantation compared with pulse cyclophosphamide once per month for systemic sclerosis (ASSIST): an open-label, randomized phase 2 trial. Lancet 2011;378:498-506.

47. van Laar JM, Farge D, Sont JK, et al. Autologous hematopoietic stem cell transplantation vs intravenous pulse cyclophosphamide in diffuse cutaneous systemic sclerosis: a randomized clinical trial. JAMA 2014;311:2490-8.

48. van Laar JM, Naraghi K, Tyndall A. Haematopoietic stem cell transplantation for poor-prognosis systemic sclerosis. Rheumatology (Oxford) 2015;54:2126-33.

49. Hügle T, van Laar JM. Stem cell transplantation for rheumatic autoimmune diseases. Arthritis Res Ther 2008;10:217.

50. van Bijnen S, de Vries-Bouwstra J, van Laar JM, et al. Predictive factors for treatment-related mortality and major adverse events after autologous haematopoietic stem cell transplantation for systemic sclerosis: results of a long-term follow-up multicentre study. Ann Rheum Dis 2020;79:1084-9.

51. Henes J, Oliveira MC, Labopin M, et al. Autologous stem cell transplantation for progressive systemic sclerosis: a prospective non-interventional study from the European Society for Blood and Marrow transplantation autoimmune disease working party. Haematologica 2021;106:375-83.
52. Assassi S, Wang X, Chen G, et al. Myeloablation followed by autologous stem cell transplantation normalises systemic sclerosis molecular signatures. Ann Rheum Dis 2019;78:1371-8.

53. Gernert M, Tony HP, Schwaneck EC, et al. Autologous hematopoietic stem cell transplantation in systemic sclerosis induces long-lasting changes in B cell homeostasis toward an anti-inflammatory B cell cytokine pattern. Arthritis Res Ther 2019;21:106.

54. Pawlak-Buś K, Schmidt W, Olejarz M, et al. Autologous hematopoietic stem cell transplant for progressive diffuse systemic sclerosis: procedural success and clinical outcome in 5-year follow up. Reumatologia 2019;57:50-4.

55. Ayano M, Tsukamoto H, Mitoma H, et al. CD34-selected versus unmanipulated autologous hematopoietic stem cell transplantation in the treatment of severe systemic sclerosis: a post hoc analysis of a phase I/II clinical trial conducted in Japan. Arthritis Res Ther 2019;21:30.

56. Del Papa N, Pignataro F, Zaccara E, et al. Autologous hematopoietic stem cell transplantation for treatment of systemic sclerosis. Front Immunol 2018;9:2390.

57. Sullivan KM, Majhail NS, Bredeson C, et al. Systemic sclerosis as an indication for autologous hematopoietic cell transplantation: position statement from the American Society for Blood and Marrow transplantation. Biol Blood Marrow Transplant 2018;24:1961-4.

58. Shenoy P, Sreenath S, Aggarwal A. Autologous stem-cell transplantation for severe scleroderma. N Engl J Med 2018;378:1066.

59. Sullivan KM, Goldmuntz EA, Furst DE. Autologous stemcell transplantation for severe scleroderma. N Engl J Med 2018;378:1066-7.

60. Shouval R, Furie N, Raanani P, et al. Autologous hematopoietic stem cell transplantation for systemic sclerosis: a systematic review and meta-analysis. Biol Blood Marrow Transplant 2018;24:937-44.

61. Sullivan KM, Goldmuntz EA, Keyes-Elstein L, et al. Myeloablative autologous stem-cell transplantation for severe scleroderma. N Engl J Med 2018;378:35-47.

62. Nakamura H, Odani T, Yasuda S, et al. Autologous haematopoietic stem cell transplantation for Japanese patients with systemic sclerosis: long-term follow-up on a phase II trial and treatment-related fatal cardiomyopathy. Mod Rheumatol 2018;28:879-84.

63. Eyraud A, Scouppe L, Barnetche T, et al. Efficacy and safety of autologous hematopoietic stem cell transplantation in systemic sclerosis: a systematic review of the literature. $\mathrm{Br}$ J Dermatol 2018;178:650-8. 
64. Farge D, Burt RK, Oliveira MC, et al. Cardiopulmonary assessment of patients with systemic sclerosis for hematopoietic stem cell transplantation: recommendations from the European society for blood and marrow transplantation autoimmune diseases working party and collaborating partners. Bone Marrow Transplant 2017;52:1495-503.

65. Trojanowska M, Varga J. Pathophysiology of fibrosis in systemic sclerosis. In: Varga J, Denton C, Wigley F, et al., (eds) Scleroderma. Springer, Cham, 2017:261-80.

66. Pope J, McBain D, Petrlich L, et al. Imatinib in active diffuse cutaneous systemic sclerosis: results of a six-month, randomized, double-blind, placebo-controlled, proof-ofconcept pilot study at a single center. Arthritis Rheum 2011;63:3547-51.

67. Bournia VK, Evangelou K, Sfikakis PP. Therapeutic inhibition of tyrosine kinases in systemic sclerosis: a review of the published experience on the first 108 patients treated with imatinib. Semin Arthritis Rheum 2013;42:377-90.

68. Prey S, Ezzedine K, Doussau A, et al. Imatinib mesylate in scleroderma-associated diffuse skin fibrosis: a phase II multicentre randomized double blind controlled trial. Br J Dermatol 2012;167:1138-44.

69. Gordon JK, Martyanov V, Magro C, et al. Nilotinib

Cite this article as: Connolly MK. Systemic sclerosis (scleroderma): remaining challenges. Ann Transl Med 2021;9(5):438. doi: 10.21037/atm-20-5449
(Tasigna) in the treatment of early diffuse systemic sclerosis: an open-label, pilot clinical trial. Arthritis Res Ther 2015;17:213.

70. Acharya N, Sharma SK, Mishra D, et al. Efficacy and safety of pirfenidone in systemic sclerosis-related interstitial lung disease-a randomized controlled trial. Rheumatol Int 2020;40:703-10.

71. Su TI, Khanna D, Furst DE, et al. Rapamycin versus methotrexate in early diffuse systemic sclerosis: results from a randomized, single-blind pilot study. Arthritis Rheum 2009;60:3821-30.

72. Asano Y, Distler JHW. Overview of animal models. In: Varga J, Denton C, Wigley F, et al., (eds) Scleroderma. Springer, Cham, 2017:281-93.

73. Herrick AL, Wigley FM, Matucci-Cerinic M. Raynaud's Phenomenon, digital ulcers and nailfold capillaroscopy. In: Varga J, Denton C, Wigley F, et al., (eds) Scleroderma. Springer, Cham, 2017:297-316.

74. Bello RJ, Cooney CM, Melamed E, et al. The therapeutic efficacy of Botulinum Toxin in treating sclerodermaassociated Raynaud's phenomenon: a randomized, doubleblind, placebo-controlled clinical trial. Arthritis Rheumatol 2017;69:1661-9. 